\title{
PETRIFIED WOOD OCCURRENCES IN WESTERN THRACE AND LIMNOS ISLAND: MINERALOGY, GEOCHEMISTRY AND DEPOSITIONAL ENVIRONMENT
}

\author{
Voudouris P. ${ }^{1}$, Velitzelos D. ${ }^{2}$, Velitzelos E. ${ }^{2}$, and Thewald U. $^{3}$ \\ ${ }^{1}$ National and Kapodistrian University of Athens, Faculty of Geology and Geoenvironment, \\ Department of Mineralogy - Petrology,voudouris@geol.uoa.gr \\ ${ }^{2}$ National and Kapodistrian University of Athens, Faculty of Geology and Geoenvironment, \\ Department of Hist. Geology - Paleontology,velitzel@geol.uoa.gr \\ ${ }^{3}$ University of Ulm/Germany, Department of Chemistry, Section of "Röntgen und \\ Elektronenbeugung”,Ulf.Thewalt@chemie.uni-ulm.de
}

\begin{abstract}
The present study describes the geology and mineralogy of the main petrified wood occurrences in Evros-Rhodopi and Limnos and integrates them in a volcanichydrothermal framework taking into consideration the nature of hydrothermal solutions during the silicification process. In the Lykofi-Fylakto-Lefkymi area, quartz and opal-CT are the main silica polymorph within the wood. The hostrocks exhibit a zeolitic alteration suggesting reduced and slightly alkaline fluids for the silicification of wood. At Kassiteres/Sappes area the presence of silicified wood within kaolinite \pm alunite altered tuffbreccias indicates that slight acidic fluids were involved in the silicification processes. In Limnos Island the fossiliferous Portianou, VarosRoussopouli and Moudros-Roussopouli areas occur in the periphery of an eroded volcanic edifice exposed at Fakos peninsula. The silicified wood occurs: (a) within weakly altered pyroclastics and (b) associated to several horizons of sinters interbedded within the pyroclastics. Transformation of amorphous silica to opal-CT and then to quartz is postulated based on XRD and SEM studies. The studied areas represent unique natural monuments, comparable to the petrified forest of Lesvos island.
\end{abstract}

Key words: silicified wood, Evros, Limnos, mineralogy, depositional environment.

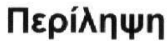

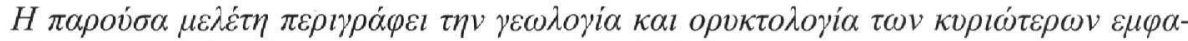

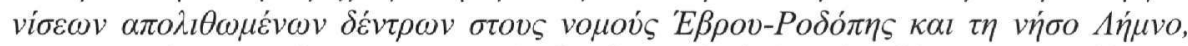

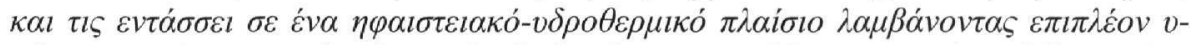

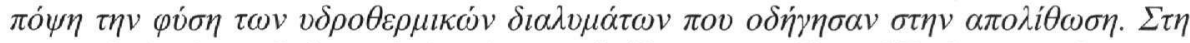

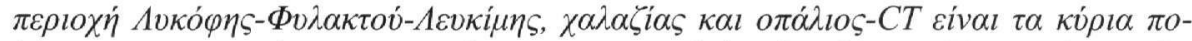

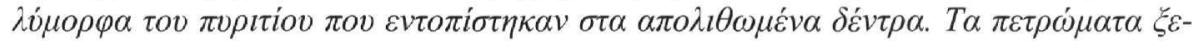

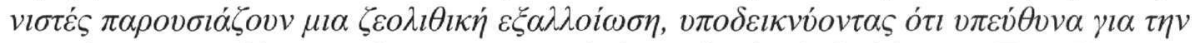

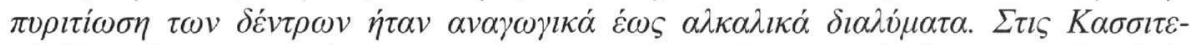

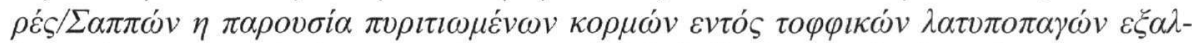

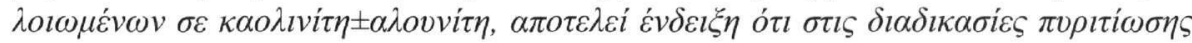




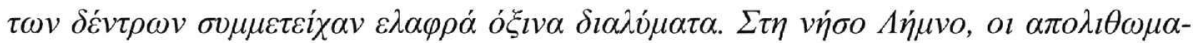

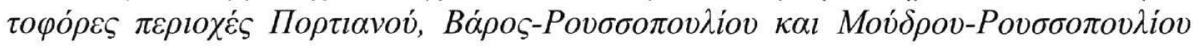

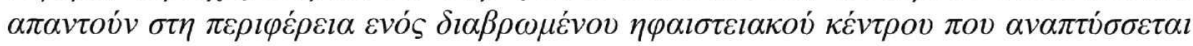

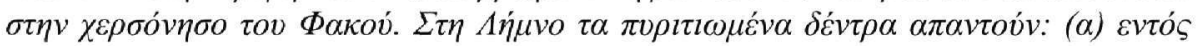

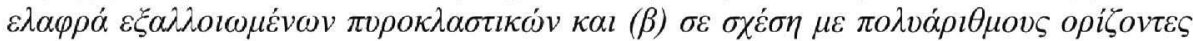

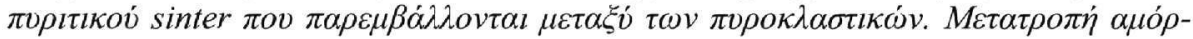

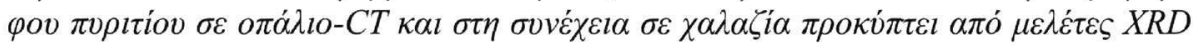

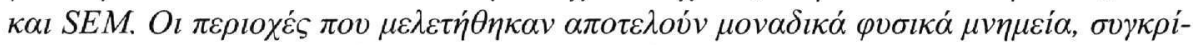

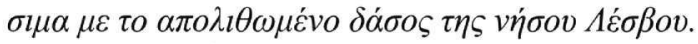

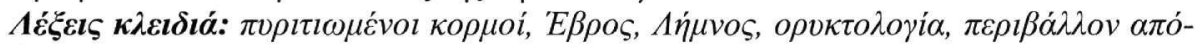
$\theta \varepsilon \sigma \eta \varsigma$.

\section{Introduction}

The northeastern Greece is a very promising district for the development of petrified forests, due to its favourable geological setting and the extensive development of orogenic Tertiary volcanoplutonic arcs. This area is characterized by widespread occurrences of petrified forests, mainly in the volcanic environments of northeastern Aegean (Evros, Limnos island, Lesvos island, Velitzelos and Zouros 1997).

This study was focused on several localities from the two broad areas, Evros and Limnos: In Evros there are several known occurrences east of Alexandroupolis, the Tychero, the Fylakto and also near the Lefkimi areas among them (Fig. 1a). Other newly discovered occurrences are those of Sapes and Perama areas (west of Alexandroupolis) and Aetochori/Pefka (east of Alexandroupolis) indicating the widespread development of petrified forests in the whole region. In Limnos island the main prospective area are the Moudros, Roussopouli, Romanou, Varos and Portianou areas (Fig. 1b).

In order to better understand the processes which resulted in the silicification of wood, this study examines the characteristics of the magmatic-hydrothermal and geothermal systems that were developed during the past in the studied areas. The evolution of these systems was the main factor controlling the circulation of silica-enriched fluids responsible for the silicification of wood. The present study describes the geology and mineralogy of some important petrified wood occcurrences in northeastern Greece and integrates them in a volcanic-hydrothermal framework taking into consideration the nature and chemistry of hydrothermal solutions during the silicification process.

\section{Materials and Methods}

Laboratory research included optical microscopy, XRD analysis with a SIEMENS type D-500 instrument, SEM analysis using a DSM 962 Zeiss Digital Scanning Microscope, at 5kV, $0.74 \mathrm{nA}$ both performed in the Section of "Röntgen und Elektronenbeugung", Department of Chemistry, University of Ulm/Germany. Selected samples were analyzed for major and trace elements using XRF method with a Phillips PW 1220 instrument in the Institute of Mineralogy and Petrology, University of Hamburg.

\section{The geodynamic evolution and volcanic activity in northeastern Greece}

The geodynamic evolution in north-eastern Greece includes an early oceanic-continental subduction/collision and post-Alpine extension resulting in the formation of back-arc basins in Rhodope and Limnos island (Krohe and Mposkos 2001). Post-collisional extensional collapse of the orogen resulted in the formation of several supra-detachment basins from the Lutetian $(48-43$ Ma) through the Oligocene up to the Pliocene. Slab break-off and/or slab delamination were principal 
mechanisms for the generation of extensive post-collisional magmatism in the area during the Oligocene to Miocene times, which greatly influenced the development of magmatic-hydrothermal systems (de Boorder et al. 1998, Pe-Piper et al. 1998, Melfos et al. 2002). The resulting plutonicsubvolcanic (monzonites, monzodiorites, granodiorites, microgranite porphyries) and volcanic rocks (banakites, trachytes, andesites, dacites, rhyolites) in Evros region show calc-alkaline, high$\mathrm{K}$ calc-alkaline, to shoshonitic affinity (Innocenti et al. 1984, Christofides et al. 1998). New K/Ar ages of volcanic rocks in this area range from 33.5 to $19.6 \mathrm{Ma}$, establishing an Oligocene and a Lower Miocene period of magmatic activity (Pecskay et al. 2003). An enriched mantle source region for the basic to intermediate magmas and a partial melting of crystal material for the acid magmas has been documented. The magmatic rocks in the island of Limnos are of Lower Miocene age (21-18 Ma) and display an orogenic character and calc-alkaline to shoshonitic affinity (Fytikas et al. 1979, 1984, Innocenti et al. 1994). The geochemical character of the Limnos magmatic rocks indicates fractional crystallization processes in the boundary between continental crust-mantle related to an enrichment of the melts in $\mathrm{K}_{2} \mathrm{O}$ and LILE elements.

\section{Description of the petrified wood occurrences in Greece}

\subsection{Evros region}

\subsubsection{Regional geology}

In Evros region the Cenozoic magmatic activity is closely related to the development of basincontrolled volcano-sedimentary formations which cover discordantly the basement rocks of the Rhodope massif and Circum Rhodope Belt (Papadopoulos 1982). Initial sedimentation started at Lutetian with the deposition of a basal-clastic formation, composed of conglomerates and sandstones overlain by a Priabonian clay-marl formation including marls alternated with sandstones and conglomerates and intercalations of lignitic horizons at the upper levels. The main phase of the Tertiary magmatism took place during the Oligocene (Innocenti et al. 1984, Kyriakopoulos 1987, Del Moro et al. 1988) and is represented by submarine/terrestrial volcanics and subvolcanic rocks, associated with volcano-sedimentary series composed of marls, sandstones, clays and intercalations of lavas, tuffs and pyroclastics.

\subsubsection{Fylakto-Lykofi-Lefkimi-Dadia area}

The geology of the area (Skarpelis et al. 1987) includes: a) a lower series of marine Priabonian sediments, associated with andesitic lavas, b) pyroclastics and lavas of dacitic to rhyolitic composition with intercalated sediments of Lower-Upper Oligocene age. The volcanics include pyroclastic flows, air fall deposits, as well as lava flows and domes, c) Upper Oligocene shallow marine sediments dominated by sandstones, marls and conglomerates (the Provatonas series), discordantly covering the acid volcanics. The area is also dominated by ignimbrites of several meters thickness.

The Lykofi - Fylakto - Lefkymi area is characterized by numerous occurences of silicified plant fossils, hosted within the Oligocene volcano-sedimentary formations. According to Kopp (1965), Velitzelos et al. (2002, 2006), the plant fossils are mainly related to the Rupelian-Chattian lignitebearing volcano-sedimentary strata of Provatonas series (SE of Fylakto village).

In the present study three fossiliferous localities were mainly investigated: the Vrysi-Pardalos between Lyra and Lagyna (Fig. 2a), the Avgo-Pefkonas, about $500 \mathrm{~m}$ west of Fylakto (Fig. 2b) and $3 \mathrm{~km}$ north of Lefkimi. In all these localities the petrified wood occurs within the volcanosedimentary formation of Provatonas series (Fig. 2c) covering discordantly the volcanics. A shallow marine environment is indicated by the presence of coral reefs and also established by the observation of abundant mollusks within the silt layers. In the locality of Vrysi-Pardalos (Fig. 2a) silt strata with abundant leaves are overlain by sandstones and microconglomerates hosting trunks of silicified wood. In the locality of Avgo-Pefkonas near Fylakto village a very similar stratigraphy includes silt layers at the base, overlain by alternations of fine- to very coarse-grained volcano- 
sedimentary beds. Several trunks of silicified wood (up to $17 \mathrm{~m}$ long) occur within the volcanic agglomerate formation, which is composed of subrounded silicified boulders of acid volcanic rocks within a tuffitic matrix (Fig. 2c).
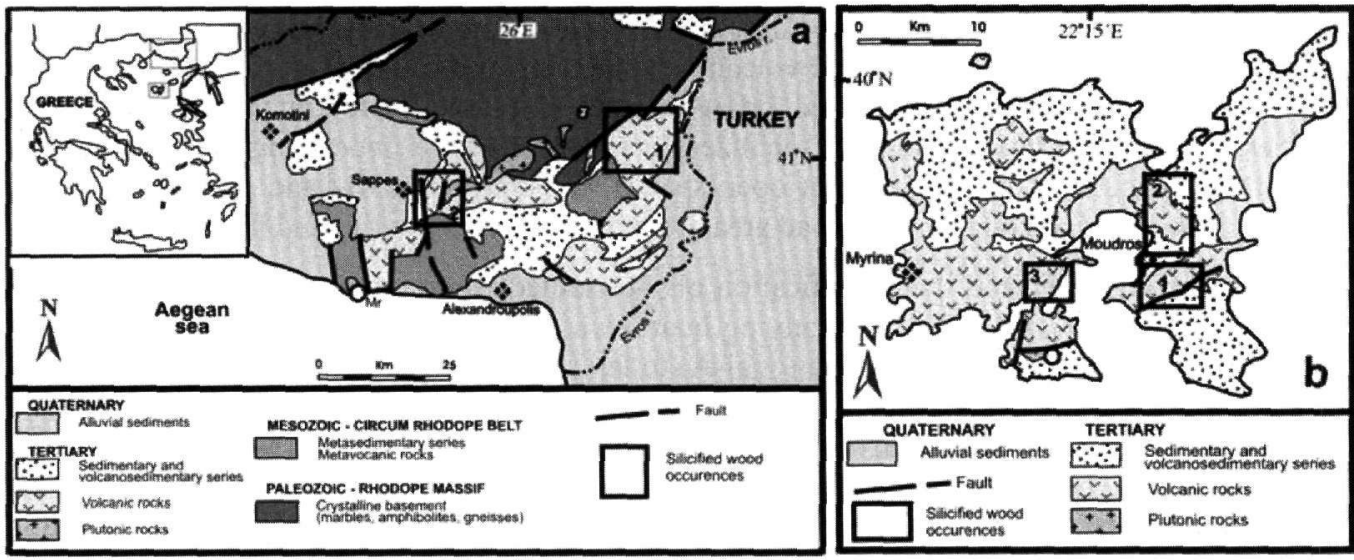

Figure 1 - (a) Geological sketch map showing the geology of the western Thrace (modified after Melfos et al. 2002) and location of the petrified-wood occurrences (1, 2); (b) Generalized geologic map of Limnos island (modified after Innocenti et al. 1994) and the Moudros

(1), Varos-Roussopouli (2), Portianou (3) petrified-wood occurrences
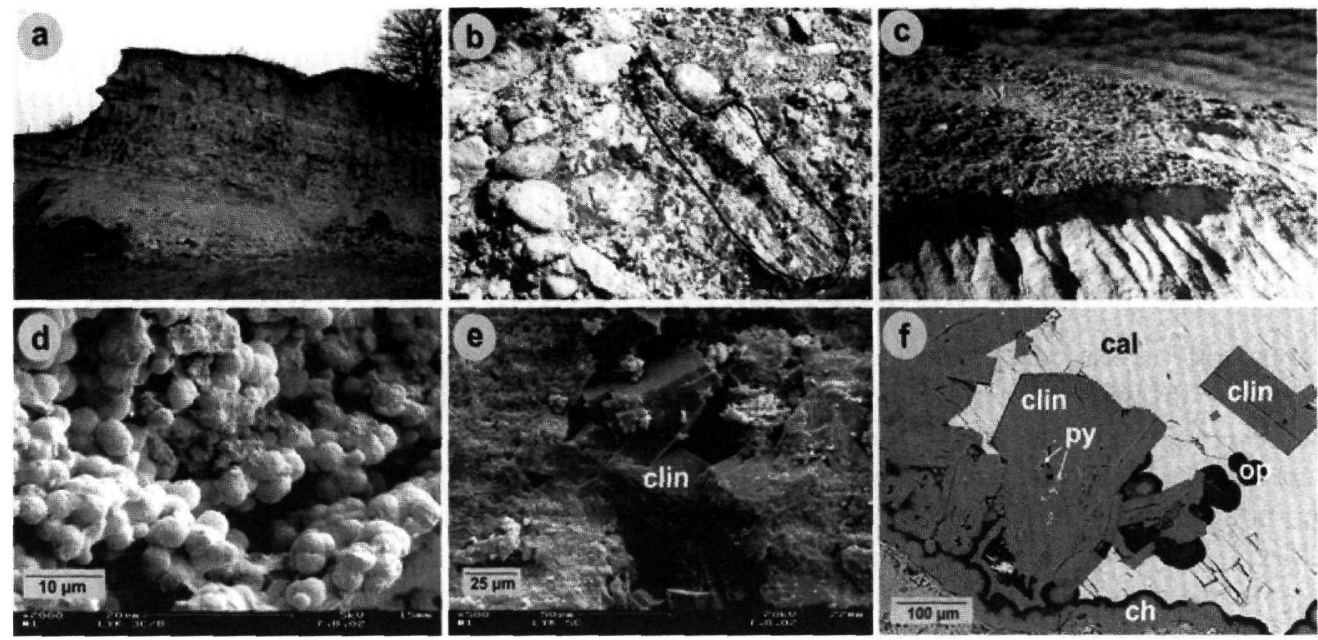

Figure 2 - (a) Location Vrysi-Pardalos: A sedimentary succession from fine-grained stratified silt (bottom) to sandstones and volcanic microconglomerates rich in silicified wood (upper parts); (b) Avgo-Pefkonas locality: Silicified trunk within volcanic agglomerate; (c) Rhyolitic lava overlain by volcano-sedimentary formation of Provatonas series; (d) Locality $3 \mathrm{~km}$ west of Lykofi. Spherolites of initial amorphous silica (opal-A) recrystallized to lepispheres of opaI-CT, SEM micrograph; (e) Clinoptilolite (clin) crystals filling vugs within silicified coral-reef limestone, SEM micrograph, locality $3 \mathrm{~km}$ south of Lykofi; (f) Clinoptilolite (clin), chalcedony (ch), opal (op) and pyrite (py) overgrown by calcite (cal). Wall-rock alteration of dacitic lavas related to amethystine/chalcedonic veining. Kornofolia locality (SEM-BSE image)

In the Lefkimi locality, andesitic hyaloclastites (suggesting a submarine environment of formation) are overlain by coral-bearing reefs and then by fine-grained volcano-sedimentary layers including silicified wood. Volcanic agglomerate strata in the Hills around Lefkimi (similar to those 
described above) are very rich in silicified wood and also contain boulders of quartz-chalcedony veins and of alunitic altered rhyolitic rocks.

It should be mentioned that the broad area is also characterized by abundant silicifications indicating intense hydrothermal activity in a shallow submarine to subaerial environment during the Upper Oligocene. The volcanic and volcano-sedimentary rocks (either of acid or intermediate composition) are overlain by opalized coral-bearing limestone reefs outcropping in several localities (e.g. south Lykofi). Both the opalized limestone and the underlying volcanic rock are crosscut by chalcedony-quartz veins. In open spaces well-formed quartz and calcite crystals are observed. The silicified zones in the broad area are accompanied by pyrite and marcasite.

The XRD analysis indicated that silicification of the studied wood material occurs mainly in the form of quartz. Some opal-CT accompanying quartz was detected in the Avgo-Pefkonas locality. A transformation from amorphous silica (opal-A) to lepispheres of opal-CT and finally to quartz is suggested by SEM analysis (Fig. 2d). The hostrock exhibits a zeolitic alteration (including clinoptilolite, mordenite, adularia, calcite, albite, opal-CT) (Figs 3a, b), which seems to be widespread in the broad area (see also Skarpelis et al. 1987). Quartz-chalcedony veins within silicified coral reefs as well as within dacitic lavas from the broad area, also exhibit a zeolitic signature (Figs 2e, f). Representative chemical analyses of zeolitic altered hostrocks and one analysis of silicified wood from Fylakto area are presented in Table 1. Besides $\mathrm{SiO}_{2}$ and $\mathrm{H}_{2} \mathrm{O}$ (probably in the form of structural water in opal) the analysis of the wood material indicates depletion in major and trace elements (sample Fy17b, Table 1).

\subsubsection{Kassiteres/Sapes area}

The Kassiteres represents an intensively hydrothermally altered area, located near Sapes about $20 \mathrm{~km} \mathrm{NW}$ of Alexandroupolis. It consists mainly of volcanic and intrusive rocks of intermediate to acid composition. A thick volcanic sequence consisting of lava domes, flows and pyroclastics dominates the western and northern part of the Kassiteres area. The close spatial relationship of lava flows, domes, and pyroclastics with intrusive bodies of similar geochemical and petrographical characteristics suggest that the Kassiteres area has been a volcanic centre, probably a single or a composite stratovolcano.

The majority of magmatic rocks in the Kassiteres-Sapes area are intensively altered as a result of repeated hydrothermal activity in the area. Alterations typical of high-sulfidation systems (White and Hedenquist 1995) are characterized by an inner silicic zone (vuggy silica), surrounded progressively by advanced argillic (quartz-alunite-kaolinite) and sericitic (quartz-sericite) alteration (Fig. 4a). Intermediate sulfidation quartz and calcite veins with related K-feldspar (adularia), sericitic and intermediate argillic alteration are developed below the advanced argillic and silicic zones. Intermediate sulfidation quartz veins crosscut the silicic bodies. The veins consist of amethystine/chalcedonic quartz with minor adularia, calcite and barite gangues (Figs 4b, c). These veins are similar to those described from the Lykofi and Lefkimi areas.

Fossilized wood trunks were found on the south of Kassiteres within altered tuffitic material (Fig. 4d). The trunks are hosted in advanced argillically altered (kaolinite alteration) tuff-breccias developed laterally of the silicic and alunitic alteration zone (Figs 4a, e, f). Quartz/chalcedony veins including adularia and calcite crosscut the silicified trunks as well the silicified zones, postdating their formation. Similarly to the results obtained from the Fylakto-Lefkimi area, the silicification in the Kassiteres wood consists almost entirely of quartz. Chemical analyses indicate total $\mathrm{SiO}_{2}$ contents of 96.2-97.01 wt\% whereas small amounts of $\mathrm{Al}_{2} \mathrm{O}_{3}$ and $\mathrm{H}_{2} \mathrm{O}$ are attributed to the presence of kaolinite (samples KassA1-A2, Table 1). $\mathrm{Fe}_{2} \mathrm{O}_{3}$ up to $0.70 \mathrm{wt} \%$ is attributed to the presence of iron oxides. 

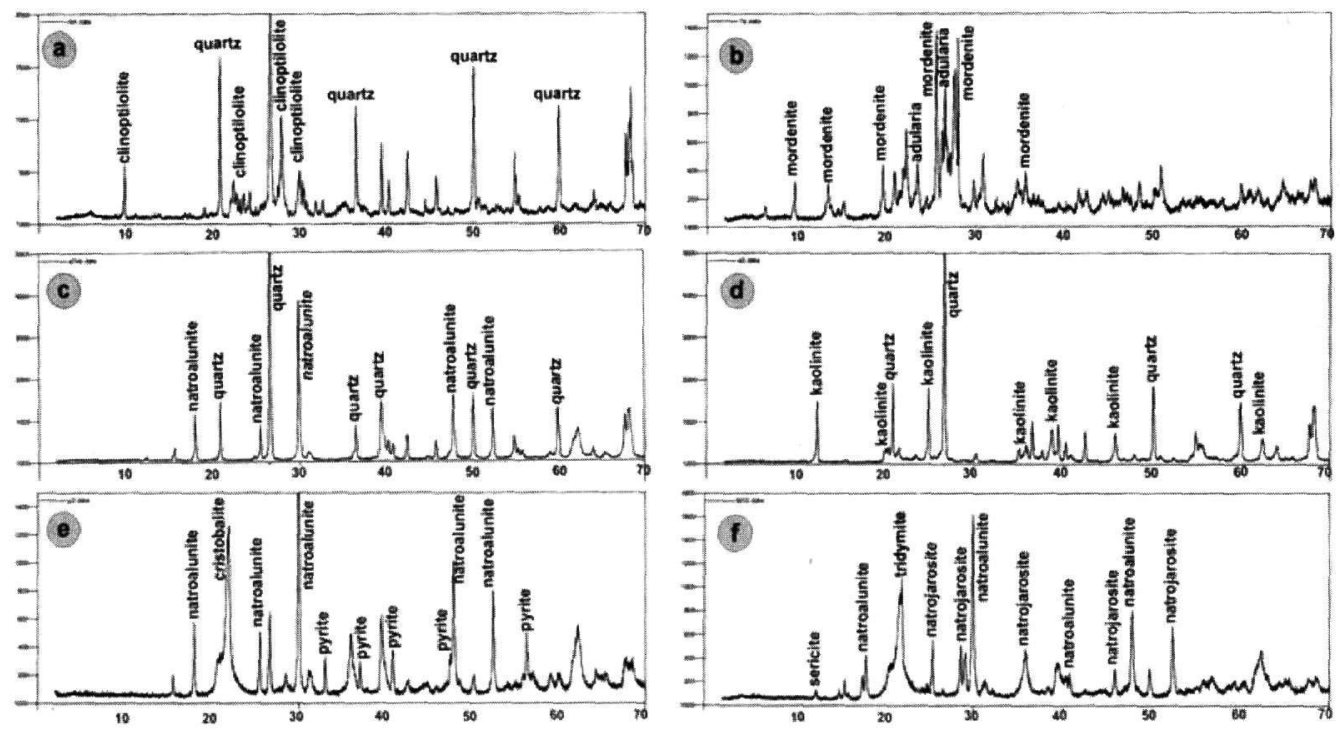

Figure 3 - XRD diagrams indicating various mineral associations within volcanosedimentary rocks hosting silicified wood. a) Avgo-Pefkonas: Quartz-clinoptilolite alteration of fine-grained volcano-sedimentary layer hosting woods; b) Avgo-Pefkonas: zeolitic altera-

tion (mordenite+adularia) of volcanic fragment from the volcanic agglomerate hosting woods; c) Kassiteres: Advanced argillic (quartz-natroalunite) alteration of tuff-breccia adjacent to the silicified wood; d) Kassiteres: quartz-kaolinite alteration of silicified wood hostrock; e, f) natroalunite in hydrothermaly brecciated silicic and advanced argillic alteration zones from Moudros and Roussopouli areas
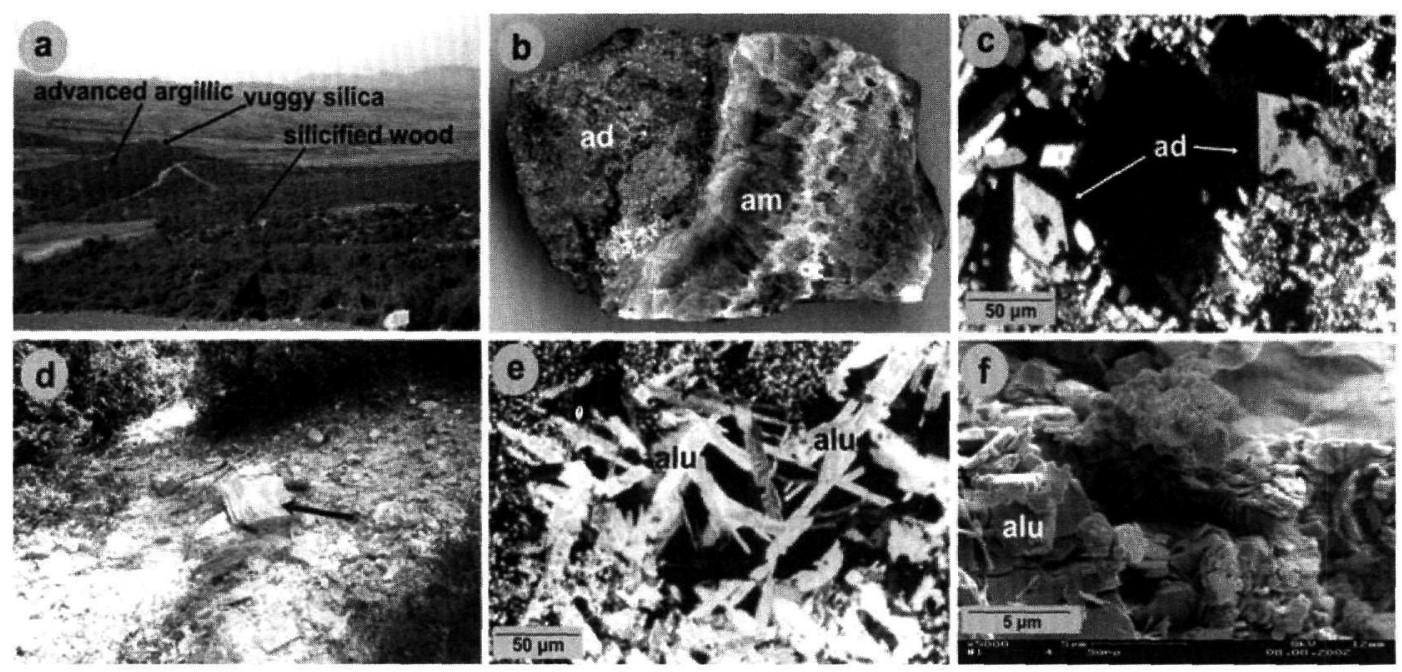

Figure 4 - (a) Silicic alteration (vuggy silica) surrounded and underlying by advanced argillic (quartz-alunite, quartz-kaolinite) and sericitic (quartz-sericite-kaolinite) alteration). Location of silicified wood at Kassiteres area; (b) handspecimen showing colloform banding between amethystine and chalcedonic silica and quartz-adularia rich wallrock alteration (10 cm long); (c) idiomorphic adularia crystals (ad) from the quartz-adularia alteration zone of a dacitic andesite (+ nicols); (d) silicified wood within kaolinite altered tuff-breccia; (e) laminated alunite crystals of replacement origin and quartz, west of Kassiteres (+ nicols); (f) Platy alunite from the wallrock alteration of tuff-breccia hosting silicified wood 


\subsection{Limnos island}

\subsubsection{Regional geology}

The geology of Limnos island is characterized by a sedimentary basement including molassic deposits of Middle Eocene - Lower Miocene age, covered by volcanic products (lava domes, flows and pyroclastics) of Lower Miocene age and by an Upper Quaternary sedimentary formation (Davis 1960, Roussos 1993, Innocenti et al. 1994). A subvolcanic body of quartz monzonitic composition intrudes the volcanics and sediments in the southern part of Fakos peninsula (Fig. 1b). Intense hydrothermal alteration and quartz veining in Fakos area (Voudouris and Skarpelis 1998) are very similar to those described from Kassiteres in Evros region.

Most of the island is covered by volcanic rocks, subdivided (according to Innocenti et al. 1994) into three major units: Katalako, Romanou and Myrina Units. The Romanou Unit is the main host of the petrified woods in Limnos island. It consists of up to $160 \mathrm{~m}$ thick pyroclastic flow deposits, which extent over broad areas mainly around the Moudros gulf (Fig. 1b). This unit (intercalated between the Katalako and Myrina units) is dominated at the base by white-colored pyroclastic flows, rich in lithic components and pumiceous fragments, followed by intercalations of ignimbrites, volcanic breccias and pyroclastis flows. The pyroclastic rocks of the Romanou Unit are classified as K-rich dacites to latites and are radiometrically dated as $19.8 \mathrm{Ma}$ old (Innocenti et al. 1994).

\subsubsection{Moudros-Roussopouli-Varos-Portianou}

Silicified wood-bearing pyroclastic beds are abundant on the eastern part of Limnos island (Figs $1 \mathrm{~b}, 5$ ). During this study three broad areas were examined, namely those of south Portianou, the Varos-Roussopouli and Moudros-Roussopouli. The stratigraphy in these areas consists of tuffitic layers at the base, overlain by volcaniclastic material (Figs $5 \mathrm{a}, \mathrm{b}, \mathrm{d}$ ). In places lava domes and flows penetrate the pyroclastics along the same orientation (NE-SW) as the fault zones in the area.

The broad Moudros-Roussopouli area is characterized by abundant manifestations of hydrothermal activity, similar to those of Evros region. The following hydrothermal alteration zones were distinguished: silicic, advanced argillic and argillic (smectite-kaolinite). The silicic alteration zones (Fig. 5f) are wedge shaped and related to the fault systems developed on the area trending $\mathrm{N} 70 \mathrm{E}$ and $\mathrm{N} 40 \mathrm{~W}$. It grades outwards to advanced argillic (alunitic), argillic (smectite-kaolinite) alteration and then to fresh rock. The silicification is microcrystalline, massive with colours varying between white, grey and black, the later due to the presence of disseminated pyrite and marcasite. Alunite and anatase are minor constituents of the silicic alteration zone. The silicic zones are crosscut by several hydrothermal breccia bodies, consisting of angular silicified fragments surrounded by an iron oxide-rich matrix (Fig. 5i). In the silicic alteration zone no fossilized wood have been observed. The alunite zone (sample M2, Table 1) is composed of silica polymorphs, natroalunite, natrojarosite, and kaolinite (Figs 3e, f). Acicular alunite crystals (Fig. 5j) occur together with quartz, kaolinite and pyrite as replacements of plagioclase, amphiboles, biotite and pyroxene phenocrysts. Hydrothermal breccias also occur within the alunite zone. The assemblage kaolinite-smectite-pyrte is well developed both laterally, as well as beneath the alunitic zone.

Silicified wood occur in two distinct environments:

A) In slighly altered (argillic alteration) pyroclastics, and typical examples are found in Varos and Portianou. Near Varos village several meters long trunks occur. The Portianou (and also Moudros) localities include in situ silicified wood hosted within the pyroclastics (Fig. 5c).

B) In several layers of opaline, "silica sinter"-similar, silicification extending from Moudros to Roussopouli. The fossiliferous zones [already described by Papp (1953)] are intercallated between the pyroclastic beds and are up to $3 \mathrm{~m}$ thick each. At least six silica sinter horizons have been recognized (Fig. 5d). According to Papp (1953) these horizons represent thin bedded lacustrine- 
able 1 - Representative XRF analyses of silicified wood and wall-rocks from Evros and Limnos areas

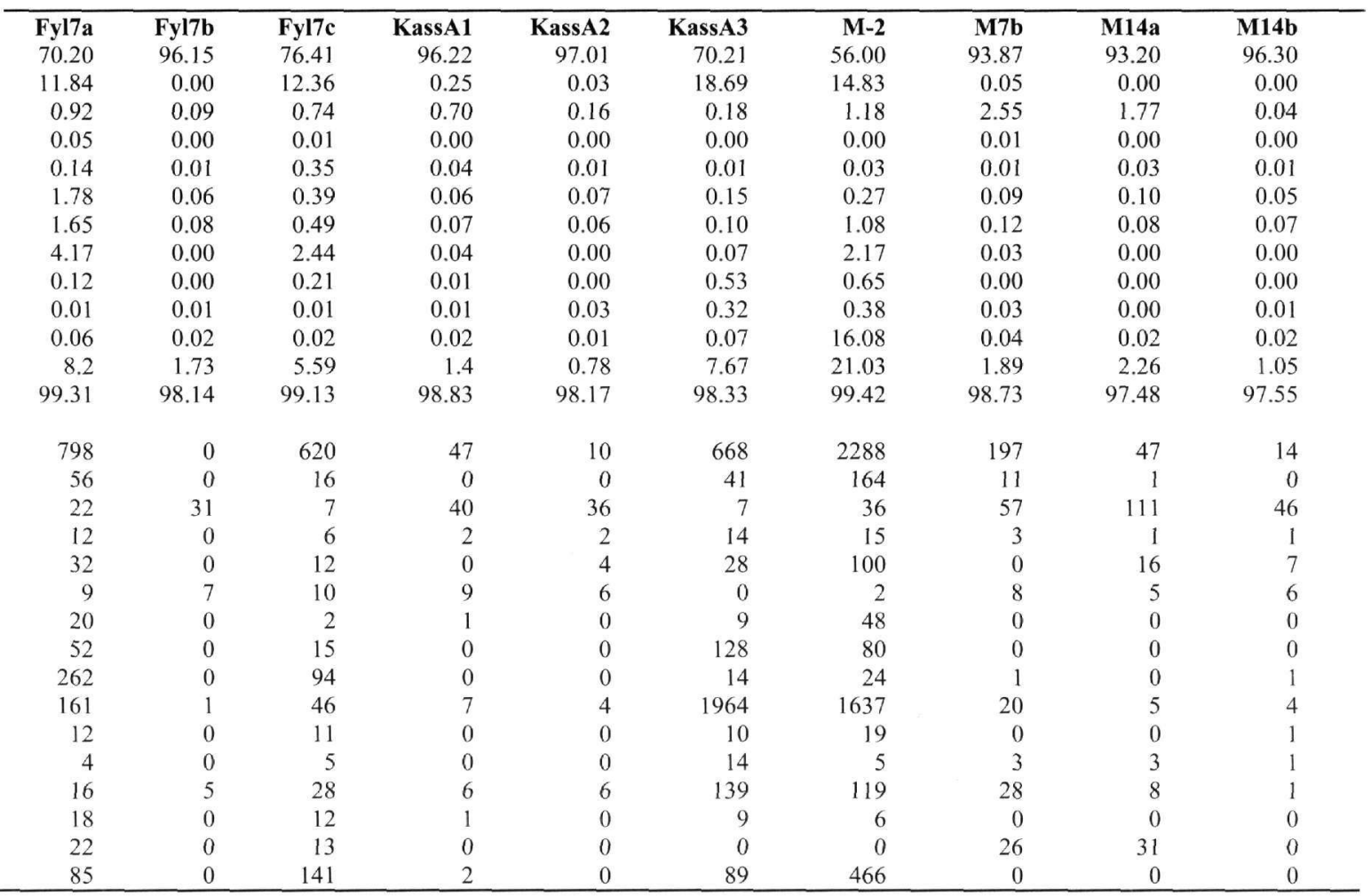

trace elements in ppm; $\mathrm{Fe}_{2} \mathrm{O}_{3}{ }^{*}=$ total iron as $\mathrm{Fe}_{2} \mathrm{O}_{3}$; Lyk5b: zeolitic altered acid volcanic rock, Fyl7a: zeolitic altered (mordenite + adularia) i Avgo-Pefkonas, Fyl7b: silicified wood composed of opal-CT and quartz from Avgo-Pefkonas, Fyl7c: zeolitic altered matrix (quartz+adu Avgo-Pefkonas. KassA1: silicified wood from Kassiteres, KassA2: silicified wood from Kassiteres, KassA3: advanced argillic altered (qu ;iteres. M2: advanced argillic altered rocks containing quartz+natrolalunite from Moudros, M7b: silicified wood, M14a: Red opal horizon ored silicified wood from the previous horizon, M21a: black colored silicification with plant material, M21c: silicified wood 



Figure 3 - Portianou locality. (a) A succession from volcano-sedimentary (sandstone like tuffite) to volcaniclastic material made up by angular to subangular andesite-dacite fragments. (b) Close-up to the upper volcaniclastic formation as in Fig. 4a, (c) Silicified wood within the basal tuffite. Moudros-Roussopoulis area: (d) Volcanic agglomerate formation at the base (up to $20 \mathrm{~m}$ thick) is overlain by pyroclastic flow units. Several fossiliferous opalized "sinter" horizons (sint) are intercalated between relatively fresh volcanics (e) Close-up of the basal volcanic agglomerate formation from previous figure. (f) View towards Roussopouli. Hypogene silicic and advanced argillic alteration zones. (g) Tilted opalized horizon rich in silicified wood overlies alunitized pyroclastics. (h) Opalized horizon including silicified wood overlies pyroclastic material (i) Hydrothermal breccia composed of silicified and alunitized rock fragments within a matrix rich in Fe-oxides. SEM-micrographs of various mineral phases from Roussopouli-Moudros area. (j) Alunite crystals in vugs of advanced argillic altered rocks at Roussopouli (k) Lepispheres of opal-CT recrystallized after amorhous silica (opal-A) in advanced argillic altered hydrothermal breccia, near Moudros (l) Tridymite (?) crystals on silicified wood from Moudros 
fluviatile intercalations between the pyroclastic formations and were deposited during erosional periods that lasted between the volcanic activity phases. The pyroclastic hostrocks demonstrate varying degrees of hydrothermal alteration. In some places the fossiliferous horizons overly an alunitic alteration zone and hydrothermal breccias rich in natroalunite (Fig. $5 \mathrm{~g}$ ) whereas the wood occurs as breccia fragments. Usually the opaline horizon is intercalated between fresh rocks. Perfectly preserved leaves indicate quiescent conditions during the fossilization procedure. The fossiliferous silicified horizons are crosscut by later chalcedony veins. Silicification in both the "silica sinter", as well as within the wood material, varies from red and white, to black colour. The white colour resulted of total depletion of iron oxides (see sample M14b, Table 1). In general there is a depletion of major and trace elements in silicified sinter and wood. Elevated $\mathrm{Fe}_{2} \mathrm{O}_{3}$ content (up to $2.6 \mathrm{wt} \%$ ) is related to the presence of iron oxides and contributes to the red colour of the silicification (Table 1). XRD-studies indicated mainly quartz as the stable silica phase within the wood. Transformation of amorphous silica to opal-CT and then to quartz is postulated based on XRD and SEM studies (Fig. 5k).

The field observations indicate that there is a close spatial and probably genetic relationship between the silicic-alunitic alteration zones and the fossiliferous silica layers. In any case there is a lateral transition and evolution of the above mentioned alteration zones laterally and upwards in stratiform fossiliferous silicification.

\section{Discussion-Conclusions}

Recent studies confirmed that the silicification of wood begins as a process of open space filling and not as a replacement of organic material by $\mathrm{SiO}_{2}$ (Roessler 2001). It seems to be controlled by diffusion of microscopic particles of $\mathrm{Si}(\mathrm{OH})_{4}$, (molecules) within the wood structure. Under this aspect the deposition of $\mathrm{SiO}_{2}$ could be resulted without destruction of the organic structure of the wood. However in advanced stages of silicification a removal of organic material is also possible (Roessler 2001).

This study demonstrates a close genetic relationship between the silicification processes leading to petrified forests in Evros and Limnos, and the hydrothermal alterations which were developed during the waning stages of volcanic activity. Alterations typical for magmatic-hydrothermal systems cover extended areas in Evros region (Kassiteres-Sapes, Loutros-Pefka, and the StavrosGerakina locality northwest of Lefkimi) and Limnos island (Fakos peninsula and the MoudrosRoussopouli areas. These alterations have a mineralogy which indicates reaction of the volcanic rocks with acid sulfate-chloride waters of magmatic-hydrothermal origin, with $\mathrm{pH}$ values even smaller than 2 and at elevated temperatures (according to White and Hedenquist 1995). In addition these fluids were generated after condensation of magmatic vapors rich in $\mathrm{SO}_{2}$ and $\mathrm{HCl}$ in groundwater present within the volcanic edifices. The late development of quartz-chalcedony rich veins accompanying a K-feldspar (adularia) alteration of the wall-rocks (Kassiteres, LykofiLefkimi), is characteristic of deposition by more reduced and neutralized geothermal fluids. This indicates an evolution from a reactive magmatic-hydrothermal system dominated by magmatic gases, to a geothermal system that is dominated by meteoric and/or seawater, in common with many other places in the world (Henley and Ellis 1983). Figure 6 shows the depositional environment of silicified wood studied, within a volcanic-hydrothemal framework.

The silicified wood observed south of the Kassiteres area, occurs within argillically altered (kaolinite alteration) tuffs and in close proximity to silicic and advanced argillic alteration zones. Available data indicate that silicification of wood in Kassiteres took place in a two-stage procedure: firstly by slightly acid fluids as they were migrating away from the advanced argillic alteration zone, and secondly by more reduced and neutralized fluids as late quartz-chalcedony veins crosscuting the wood. A similar process has been also described for the silicification of wood in Chemnitz, Germany (Roessler 2001). 


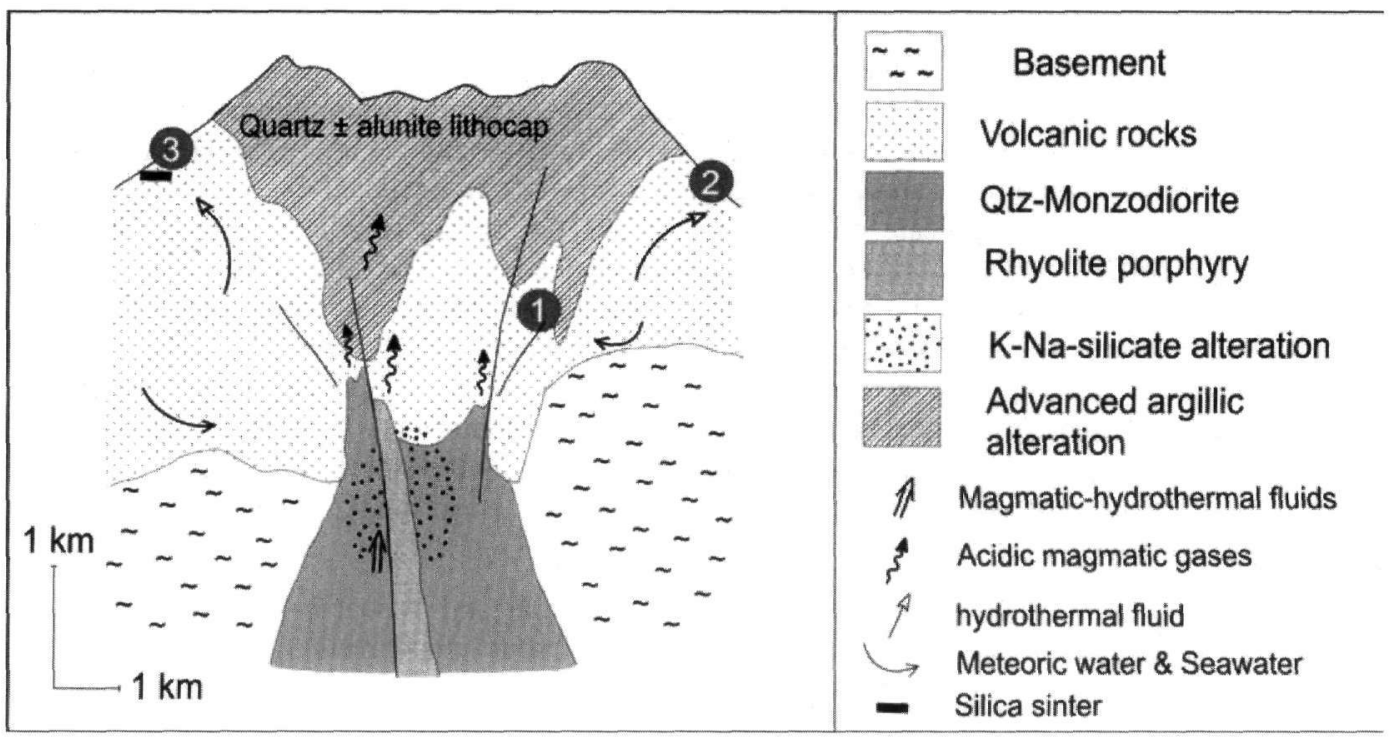

Figure 4 - Hypothetical model demonstrating depositional environment of silicified wood occurrences in Kassiteres (1), Lykofi-Fylakto-Lefkimi (2) and Limnos island (3)

In contrast to Kassiteres area, the fossilized occurrences of Fylakto, Lefkimi, etc., are lying some $\mathrm{km}$ away from the supposed highly reactive magmatic-hydrothermal center near Stavros locality. Responsible for the silicification of trees were reduced and near neutral $\mathrm{pH}$ fluids as demonstrated by the alteration mineralogy of the broad area (zeolitic alteration). Reduced and near neutral $\mathrm{pH}$ fluids were also depositing the abundant quartz-chalcedony veins crosscuting all the formations in the broad Fylakto-Lykofi-Lefkimi area.

In Limnos island, the Fakos peninsula has been recognized as a Cenozoic magmatic-hydrothermal center with characteristics comparable to those of Kassiteres area. The central parts of the volcanic edifice are occupied by silicic and advanced argillic alteration zones of magmatic-hydrothermal origin. The silicified wood occurs in the periphery of Fakos but in very close proximity to large scale fault zones that facilitated the circulation of hydrothermal fluids. Although the petrified trunks found within relatively fresh pyroclastics, could have been formed partly by devitrification processes by near neutral $\mathrm{pH}$ fluids, a hydrothermal deposition of silica is established for the wood present in the silicified horizons between Moudros and Roussopouli. The silicified horizons probably correspond to swamp depressions, which were flooded by the upwelling hydrothermal fluids. Field observations indicate a scenario of contemporaneous formation between the horizons and the silicic and advanced argillic alteration zones in a hot spring environment. The horizons probable represent lateral surface manifestations of the above alteration zones. Neutralization was resulted as the fluids migrated away from the acidic outflow zones. Alternatively some of the horizons could represent true silica sinter formations (like the Rhynie chert in Schottland, Rice et al. 2002), deposited from near neutral fluids and not directly related to the silicic and advanced argillic alteration zones. This scenario requires distinct periods of formation and is a matter of further investigation. The Evros and the Moudros-Roussopouli areas represent unique natural monuments in Greece, comparable to the Lesvos island petrified forest (Velitzelos et al. 2002) and belong to the Greek mineralogical and geological heritage. Ongoing work aims to constrain the details about the mechanisms resulting in the silicification of wood in Evros and Limnos regions.

\section{Acknowledgments}

Mrs G. Doerfner is especially thanked for the XRD measurements in the University of Ulm. 


\section{References}

Christofides, G., Soldatos, T., Eleftheriadis, G., and Koroneos, A., 1998. Chemical and isotopic evidence for source contamination and crustal assimilation in the Hellenic Rhodope plutonic rocks, Acta Vulcanologica, 10, 305-318.

Davis, E., 1960. The volcanic rocks of Lemnos island, Ann Geol Pays Hellen, 11, 1-82.

De Boorder, H., Spakman, W., White, SH., and Wortel, MJR., 1998. Late Cenozoic mineralization, orogenic collapse and slab detachment in the European Alpine Belt, Earth Plan Sc Lett, 164, 569-575.

Del Moro, A., Innocenti, F., Kyriakopoulos, C., Manetti, P., and Papadopoulos, P., 1988. Tertiary granitoids from Thrace (Northern Greece): $\mathrm{Sr}$ isotopic and petro- chemical data, $N J b$ Miner Abh, 159, 113-135.

Fytikas, M., Giuliani, O., Innocenti, F., Manneti, P., Mazzuoli, R., Peccerillo, A., and Villari, L., 1979. Neogene volcanism of the Northern and Central Aegean region, Ann Geol Pays Hell, 30, 106-129.

Fytikas, M., Innocenti, F., Manneti, P., Mazzuoli, R., Peccerillo, A., and Villari, L., 1984. Tertiary to Quaternary evolution of volcanism in the Aegean region, In J.E. Dixon and A.H.F. Robertson (eds), The geological evolution of the eastern Mediterranean, Geol. Soc. Spec. Publ., Oxford, 17, 687-699pp.

Henley, R.W., and Ellis, J., 1983. Geothermal systems ancient and modern: A geochemical review, Earth Sci Rev, 19, 1-50.

Innocenti, F., Kolios, N., Manetti, O., Mazzuoli, R., Peccerillo, G., Rita, F., and Villari, L., 1984. Evolution and geodynamic significance of the Tertiary orogenic volcanism in northeastern Greece, Bull Volcanol, 47, 25-37.

Innocenti, F., Manetti, O., Mazzuoli, R., Pertusati, P., Fytikas, M., and Kolios, N., 1994, The geology and geodynamic significance of the island of Limnos, North Aegean Sea, Greece, $N$ Jb Geol Palaont Mh, 11, 661-691.

Kopp, C.O., 1965. Geologie Thraziens III. Das Tertiar zwischen Rhodope und Evros, Ann Geol. Pays Hell, 16, 315-362.

Krohe, A., and Mposkos, E., 2001. Structural evolution and exhumation history of the Rhodope UHP-HP metamorphic province (Northern Greece), Bull Geol Soc Greece, 34, 75-82.

Kyriakopoulos, K., 1987. A geochronological, geochemical and mineralogical study of tertiary plutonic rocks of the Rhodope massif and their isotopic characteristics. Unpubl. Ph.D. thesis, Univ. Athens, 343pp. (in greek)

Melfos, V., Vavelidis, M., Christofides, G., and Seidel, E., 2002. Origin and evolution of the Tertiary Maronia porphyry copper-molybdenum deposit, Thrace, Greece. Mineral Deposita, $37,648-668$.

Papadopoulos, P., 1982. Geological map of Greece, Maronia sheet, 1:50.000, IGME, Athens.

Papp, A., 1953. Erläuterungen zur Geologie der Insel Lemnos, Ann Geol Pays Hell, 1-33.

Pecskay, Z., Eleftheriadis, G., Koroneos, A., Soldatos, T., and Christofides, G., 2003. K/Ar dating, geochemistry and evolution of the Tertiary volcanic rocks (Thrace, northeastern Greece). In D. Eliopoulos et al. (eds), Mineral Exploration and Sustainable Development, Millpress Publications, Rotterdam. 1229-1232pp. 
Pe-Piper, G, Christofides, G., and Eleftheriadis, G., 1998. Lead and neodymium isotopic composition of Tertiary igneous rocks. of northeastern Greece and their regional significance, Acta Vulcanologica, 10, 255-263.

Rice, C.M., Trewin, N.H., and Anderson L.I., 2002. Geological setting of the early Devonian Rhynie cherts, Aberdeenshire, Scotland: an early terrestrial hot spring system, Journal Geol. Society London 159, 203-214.

Roessler, R., 2001. Der Versteinerte Wald von Chemnitz, Museum für Naturkunde Chemnitz, 205 pp.

Roussos, N., 1993. Geological map of Greece, Myrina and Moudros sheets, Limnos island, scale 1:50.000, I.G.M.E., Athens.

Skarpelis, N., Economou, M., and Michael, K., 1987. Geology, petrology and polymetallic ore types in Tertiary volcanosedimentary terrain, Virini-Pessani-Dadia area, West Thrace (Northern Greece), Geol. Balc, 17(6), 31-41.

Velitzelos, E., and Zouros, N., 1997. The petrified forest of Lesvos - Protected natural monument, Engineering Geology and the environment, In P. Marinos, Koukis, Tsiambaos and G. Stournaras (eds), Balkema Publications, 3037-3043pp.

Velitzelos, E., Mountrakis, D., Zouros, N., and Soulakelis, N., 2002. Atlas of the Aegean geological monuments, (Ed. Aegean Ministry), 351pp.

Velitzelos, E., Velitzelos, D., Iamandei, S., and Iamandei, E.P., 2006. Tertiary petrified palm trees in Greece, 7th European Paleobotany-Palynology Conference, 6-16 Sept., Prague, 150p.

Voudouris, P., 1993. Mineralogical, geochemical and fluid inclusion studies on epithermal vein type gold-silver mineralizations at Kassiteres/Sapes, (NE-Greece), Unpub PhD thesis, Univ Hamburg, 218pp.

Voudouris, P., and Skarpelis, N., 1998. Epithermal gold-silver mineralizations in Perama (Thrace) and Lemnos, Bull Geol Soc Greece, 32(3), 125-135. (in Greek)

White, N.C., and Hedenquist, J.W., 1995. Epithermal gold deposits: Styles, characteristics and exploration, Soc Econ Geol Newsletter, 23, 9-13. 